\title{
Malignant Lymphoma and Tumor Suppressor Genes
}

\author{
Hirokazu Nagai ${ }^{12)}$, Tomohiro Kinoshita ${ }^{1)}$, Atsushi Ichikawa ${ }^{3)}$ and Takashi Murate ${ }^{4)}$
}

Various types of tumor suppressor genes (TSG) have been reported to be mutated in malignant lymphoma. Point mutation and deletion are the major mechanisms that inactivate TSG. Alterations of the p53 gene have been analyzed well in lymphoid malignancies, and point mutations have been proved to have an important role in the progression or aggressiveness of B cell lymphoma. Recently, the silencing of gene expression by DNA hypermethylation was proposed as an alternative mechanism in inactivation of TSG. The p73, p15INK4B, and p16INK4A genes are targets of such epigenetic alterations. The ATM, PTEN, and SNF5/INI1 genes are also reported to be mutated in $\mathrm{T}$ and/or $\mathrm{B}$ cell malignancies. Recurrent chromosomal deletion may indicate the loss of candidate TSGs in the deleted interval. Cytogenetic and molecular analyses have revealed frequent and recurrent hemizygous chromosomal deletions at $6 \mathrm{p}, 6 \mathrm{q}$, and $13 \mathrm{p}$ in malignant lymphoma. These deleted intervals have been intensively investigated to identify the candidate TSG that imply the pathogenesis of malignant lymphoma. As mentioned above, many TSG are mutated in malignant lymphoma, and these alterations could be critical in the development and progression of lymphoma. Comprehensive study of TSG is essential to understand the biological characteristics of malignant lymphoma.

Key words malignant lymphoma, tumor suppressor gene, chromosomal deletion

\section{INTRODUCTION}

Human neoplasms have been shown to progress through multi-step processes of genetic alteration. The deregulation of oncogenes is one of the major steps. Chromosome translocations are major genetic alterations in hematological malignancies ${ }^{1,2}$. Oncogenes usually lie close to chromosomal breakpoints and become deregulated or mutated. Several genetic loci, such as Cyclin $\mathrm{Dl}^{3,4}, \mathrm{BCL2}^{5}, \mathrm{BCL6}^{6,7}$, $\mathrm{BCL}_{10}{ }^{8}, \mathrm{ALK}^{9}$, and $\mathrm{MALT}^{10,11}$, are sometimes disrupted by specific chromosomal translocations in malignant lymphoma. They have been cloned near chromosomal breakpoints, and are now regarded as oncogenes with important roles in lymphomagenesis.

Another important genetic event beyond the

Received: Feb 7, 2001

Revised: Feb 4, 2002

Accepted: Feb 6, 2002

${ }^{1)}$ First Department of Internal Medicine, Nagoya University School of Medicine

${ }^{2)}$ Department of Hematology, Nagoya National Hospital

${ }^{3}$ Department of Hematological Oncology, Gifu Prefectural Tajimi Hospital,

${ }^{4}$ Nagoya University School of Health Science

Adress corespondence and reprint requests to Hirokazu Nagai, Department of Hematology, Nagoya National Hospital, 4-1-1 Sannomaru, Naka-ku, Nagoya, 460-0001, Japan activation of oncogenes is alteration of tumor suppressor genes (TSG). Knudson proposed the " 2 hits" theory to explain the mechanism for neoplasm development through the genetic alterations of TSG based on epidemiological observation of retinoblastoma cases ${ }^{12}$. Patients with hereditary cancer syndrome have the mutated TSG in a heterozygous germ line creating the endogenous first hit, and disruption of another copy of the TSG as the second hit will develop malignancy within the target organ. This hypothesis has been confirmed by molecular biological analyses of cases of retinoblastoma ${ }^{13}$, Wilms tumor ${ }^{14}$, Li-Fraumeni syndrome ${ }^{15,16}$ and familial polyposis of the colon ${ }^{17}$. In sporadic cases, two-hit inactivation of the TSG at both alleles should be necessary to induce malignancies of the target organ.

Inactivation of TSG has also been reported in sporadic lymphoid malignancies. Mutations of p5 $3^{18,19}$ and p16INK $4 \mathrm{~A}^{20}$ genes were found in some patients with lymphoid malignancies. p53 mutations have been demonstrated to be a significant prognostic factor ${ }^{21}$. In other words, alterations of TSG will directly affect the clinical features of lymphoid malignancies. Many other documented and putative TSG have been reported to be mutated in lymphoid malignancies. Many deleted chromosomal regions have been identified from karyotype analysis of 
lymphoma. Such frequently deleted regions might be candidates for one of the two hits of Knudson's theory. They are thought to include candidate tumor suppressor loci, which may harbor TSG. Much effort has been made in many laboratories to clone TSG from such regions.

The importance of TSG in the pathogenesis of lymphoma and the present status of the progress in cloning TSG are presented in this review.

\section{Inactivation of TSG}

\section{Point mutation}

TSG usually have been cloned as genes responsible for familial cancer syndromes. The presence of point mutations in a germ line is strong evidence of responsibility for such syndromes. Somatic mutation in sporadic tumors is also the most common mechanism for TSG inactivation. Almost all TSG and putative TSG have point mutations or small deletions in their coding regions, and these mutations usually result in amino acid substitutions and protein truncations. Some TSG have hot spots for point mutations in the biologically important region of the respective gene ${ }^{22}$. Some mutations abrogate or change the physiological function of the genes. These changes are classified as "loss of function" or "gain of aberrant function" mutations. One of the genes best known to undergo frequent point mutations is p53. Databases for p53 mutations have been constructed in various kinds of tumors ${ }^{23}$. DNA chips, which can detect p53 mutations, are designed to exploit these data.

\section{Chromosomal deletion}

Hemizygous and homozygous chromosomal deletion is another genetic change of TSG. Hemizygous deletions, which can be detected by loss of heterozygosity $(\mathrm{LOH})$ studies using polymorphic markers, are frequently found around RB, p53, WT1, p16INK4A, and p15INK4B gene loci, demonstrating one allelic inactivation of these genes. Homozygous deletions have been found in the $9 \mathrm{p} 21$ region, which contains the locus of p16INK4A and p15INK4B, and is an example of the biallelic inactivation of these genes ${ }^{20,24}$. Some candidate TSG have been cloned from regions that are homozygously deleted in sporadic malignancies ${ }^{25-27}$. These regions, which show chromosomal deletions, may indicate the presence of possible TSG.

\section{Hypermethylation of $C p G$ islands}

$\mathrm{CpG}$ islands (a GC-rich section of the genome usually found in the 5' region of genes) of transcriptionally-expressed genes remain unmethylated. Hypermethylation of the normally unmethylated $\mathrm{CpG}$ islands in the promoter regions of TSG is correlated with the loss of transcription, suggesting an alternative mechanism leading to TSG inactivation ${ }^{28-31}$.

\section{Tumor suppressor genes and candidates}

\section{1. p53 and $p 73$}

To maintain genomic stability, cells have a specific surveillance and repair system. p53, the central player in this system, is activated by the Ataxia-telangiectasia mutated (ATM) gene product in response to DNA damage ${ }^{32}$. Activated p53 can induce the cyclin-dependent kinase inhibitor, p21 (WAF1), to stop the cell cycle and allow time for the repair of damaged $\mathrm{DNA}^{33,34}$, or can induce apoptosis to remove cells with excessive genomic damage ${ }^{35}$. Recently, several genes whose transcription is induced by 553 have been cloned, including AIP $1^{36}$ and $\mathrm{p} 53 \mathrm{R} 2^{37}$. Molecular analysis of genes regulated by $\mathrm{p} 53$ is an effective method to reveal the multifunctional profile of $\mathrm{p} 53$. Through these functions p53 keeps the genome stable and suppresses the development of malignancy.

The genetic alteration of $\mathrm{p} 53$ in lymphoid malignancies has been reported by many investigators ${ }^{18,19}$. The incidence of mutations of the $\mathrm{p} 53$ gene in $B$ cell lymphoma has been reported to range from $10 \%$ to $40 \%$. Approximately $20 \%$ of aggressive B cell lymphomas, excluding lymphoblastic lymphoma and small non-cleaved cell lymphoma, show p53 mutations $^{18,21}$ A higher rate of p53 mutations was found in small non-cleaved cell lymphoma: 23 out of $59(39 \%)$ patients $^{38}$. On the other hand, low grade lymphoma showed about a $10 \%$ incidence of mutation of the p53 gene, but mutations of p53 are associated with histologic transformation in approximately $25-30 \%$ of follicular lymphoma ${ }^{39}$. These reports suggest that p53 mutations might have an important role in tumor progression or aggressiveness. In fact, a poor prognosis was correlated with p53 mutation in various kinds of human malignancies ${ }^{40,41}$.

In aggressive non-Hodgkin's lymphoma (NHL) we reported that overall survival was significantly 
lower in patients with p53 mutations than in those with wild-type p53 (5-year survival rate: $16 \%$ versus 64\%) (Fig. 1), and that p53 mutation is an important marker affecting patients' survival, independent of well-known clinical markers in the international prognostic index (IPI $)^{21,42}$. Interestingly, p53 mutation had no significant effect on the survival of patients in high and high-intermediate IPI risk groups, although this mutation was significantly associated with poor survival in low and lowintermediate risk patients (Fig 1). This finding suggested : 1) the unique prognostic significance of p53 mutation in a lower risk population and 2) the presence of factors other than p53 mutation that

\section{A All Patients}

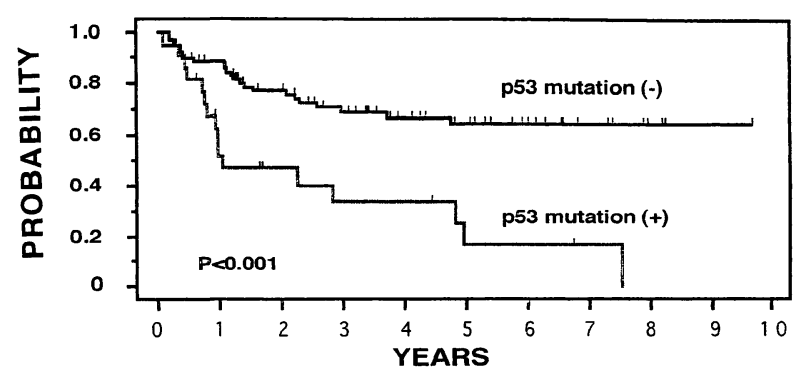

B

Patients in Lower-Risk Groups

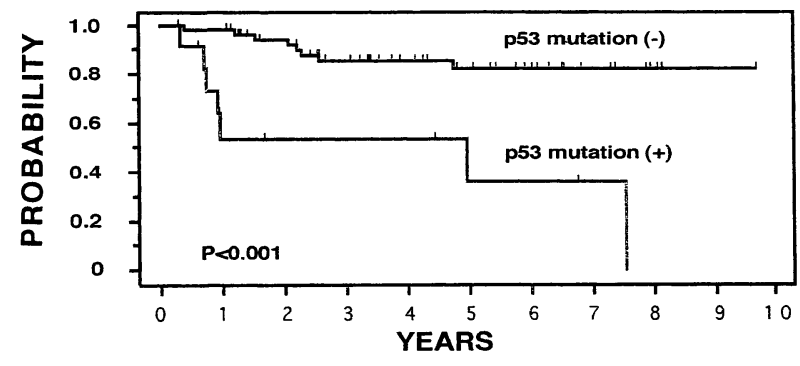

C Patients in Higher-Risk Groups

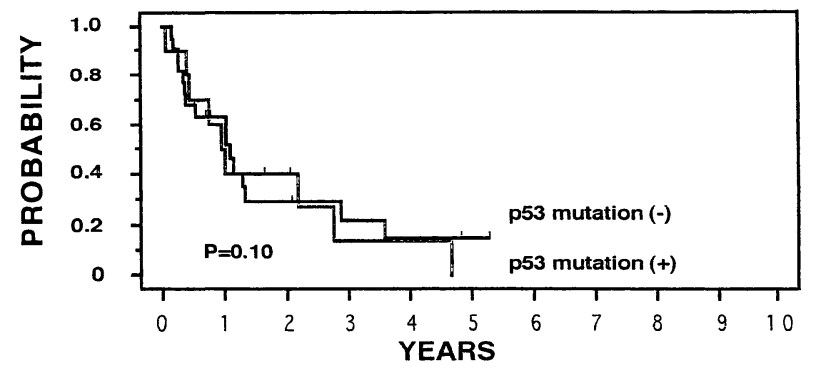

Fig. 1. Survival of patients with and without p53 mutations.

Survival with p53 mutations was significantly shorter than without p53 mutation in patients of all populations (A) and of groups at low and low-intermediate risk (B). The presence of p53 mutations did not significantly affect the survival of patients in groups at high and high-intermediate risk $(\mathrm{C})$. determine prognosis in high and high-intermediate IPI risk patients.

Recently, the p73 gene located on chromosome $1 \mathrm{p} 36$ was cloned and joined the p53 family ${ }^{43}$. The function of the $\mathrm{p} 73$ gene resembles that of $\mathrm{p} 53$, in terms of inducing p21 (WAF1) expression and resulting in G1 arrest and induction of apoptosis. Because of its chromosomal location, p73 was once thought to be a candidate TSG for neuroblastoma, but a recent study suggested less involvement in the development of neuroblastoma ${ }^{44}$. Kawano, et al. found no genetic changes in the p73 gene in lymphoid malignancies, but loss of mRNA expression and hypermethylation of the $\mathrm{CpG}$ island of the 5', untranslated region, of the p73 gene were observed in acute lymphocytic leukemia (ALL) / B-NHL cell lines as well as in primary lymphoid tumors ${ }^{45}$. These data linked epigenetic changes in the p73 gene to development and/or progression of lymphoid neoplasms.

\section{ATM and DNA repair genes}

Ataxia telangiectasia (AT), an autosomal recessive disorder characterized by cerebellar degradation, immunodeficiency, occulocutaneous telangiectasia, genome instability, cancer predisposition and radiation hypersensitivity, is caused by mutations of a gene named ATM. It encodes a $350 \mathrm{kDa}$ serine-threonine kinase and is located at $11 \mathrm{q} 22$ $23^{46,47}$. ATM recognizes DNA-double strand breakage after ionizing radiation and activated ATM can phosphorylate the checkpoint kinase Chk2. The phosphorylated Chk2 can then phosphorylate p53. Using this cascade, DNA damage will result in

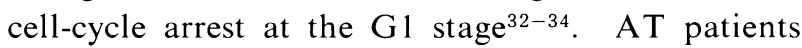
show a marked predisposition to develop $\mathrm{T}$ and $\mathrm{B}$ cell lineage malignancies.

T-prolymphocytic leukemia (T-PLL) has been analyzed for mutations of the ATM gene. The majority of sporadic T-PLL are reported to have a hemizygous chromosomal deletion at 11q22-23, which contains the ATM gene, and showed missense mutations in the ATM gene on the remaining allele ${ }^{48}$. These reports demonstrated that somatic inactivation of ATM was involved in the pathogenesis of sporadic T-PLL and that ATM acted as a TSG in sporadic tumors of non-AT cases. Recently, biallelic mutations of the ATM gene were reported in 7 out of 12 mantle cell lymphomas ${ }^{49}$. Alteration of the ATM gene was proved to be involved in both $\mathrm{B}$ cell and $\mathrm{T}$ cell lineage malignancies. 


\section{H. Nagai at al}

The NBS1 gene product is a component of the complex of DNA double strand breakage repair machinery and is located at chromosome $8 \mathrm{q} 21$. Patients suffering from Nijimegen syndrome, a cancer-predisposing disorder, have germ line point mutations in the NBS1 gene ${ }^{50}$. Our preliminary study identified somatic missense mutation of the NBS1 gene in some malignant lymphoma patients (unpublished data). A breakdown in the DNA repair system might have a role in the pathogenesis of malignant lymphoma.

\section{3. p15 and p16, INK4 family}

Chromosome 9 p21 is a frequent site of deletions and rearrangements in many tumors, including leukemia, implying the existence of a TSG within this region ${ }^{51,52}$. The type-1 interferon gene clusters were mapped to this region, and were originally suggested as the target for the deletion in leukemia. Later studies, however, revealed that p16INK4A, one of the cyclin dependent kinase (CDK) inhibitors for CDK 4 and $\mathrm{CDK}^{53}$, was located in this region and possessed the basic genetic characteristics of $\mathrm{TSG}^{54,55}$

The activity of CDK, which regulates the cell cycle progression of eukaryotic cells, is modulated by complex mechanisms including the expression of cyclins and CDK inhibitors and the phosphorylation of CDK. CDK inhibitors are thought to be negative regulators of the cell cycle, so the disruption of these genes will result in uncontrolled cell cycle progression and cell proliferation. p15INK4B, which shows a high homology to pl6INK4A, is located in the same region ${ }^{54}$, and may act as an effecter of transforming growth factor- $\beta$ mediated cell cycle arrest ${ }^{56}$.

High-frequency homozygous deletions involving the p16/p15 locus were reported in ALL, especially in leukemia of $T$ cell lineage (about half of cases) ${ }^{24,57}$. Such deletions and somatic mutations of p16INK4A are not so frequent in $B$ cell lymphoma $a^{20,58,59}$. Some investigators have found genetic alterations of p16INK4A in adult $T$ cell leukemia/lymphoma (ATLL) at relatively high frequency $^{60}$. The homozygous deletions in the $\mathrm{p} 16 / \mathrm{p} 15$ locus seem to be associated with the progression toward high-grade tumor ${ }^{61,62}$.

Hypermethylation of the INK4 family has also been studied in various types of tumors, including hematological malignancies. Selective inactivation by hypermethylation of either p16INK4A or

\section{J. Clin. Exp Hematopathol}

Vol. 42, No. 1, May 2002
p15INK4B has been observed in hematological malignancies according to the respective tumor type $^{31,63-66}$. Methylation of p15INK4B, for example, occurs frequently in acute myeloid leukemia (AML), ALL and myelodysplastic syndrome (MDS), but methylation of p16INK4A in AML, ALL and MDS appears to be rare. Both methylation of p16INK 4A and p15INK4B in multiple myeloma was found with a high frequency. In contrast, neither pl6INK4A nor p15INK4B are methylated at any stage of chronic myelogenous leukemia (CML).

In malignant lymphoma, both p16INK4A and p15INK4B have been reported to be frequently methylated $^{67}$. The reported methylation of p15INK4B and p16INK4A genes was $64 \%$ and $32 \%$ of B cell lymphomas, and $44 \%$ and $22 \%$ of $\mathrm{T}$ cell lymphomas, respectively. Because high-grade B cell lymphoma showed more frequent methylation of p15INK4B and p16INK4A (78\% and 50\%, respectively) than low grade B cell lymphomas ( $55 \%$ and $21 \%$, respectively), the p15 and pl6 gene silencing by methylation is suggested to be associated with aggressiveness of lymphoma.

The INK4A locus gives rise to a transcript called p14/19ARF gene that is separate from p16INK4A and transcribed from another exon using a different reading frame ${ }^{68}$. p14/19ARF can arrest the cell cycle in a p53-dependent manner. p14/ 19ARF binds to MDM2 and promotes the rapid degradation of $\mathrm{MDM}^{69}$. p14/19ARF-promoted MDM2 degradation is associated with MDM2 modification and concurrent p53 stabilization and accumulation.

The functional consequence of p14/19ARFregulated $\mathrm{p} 53$ levels via MDM2 proteolysis is evidenced by the ability of ectopically-expressed p14/ 19ARF to restore a p53-imposed G1 cell cycle arrest that is otherwise abrogated by MDM2. These functional aspects of p14/19ARF may explain the route of unregulated cell proliferation and tumor development when it is inactivated. In primary tumors and cell lines, the majority of biallelic deletions of pl6INK4A extend to include the first exon of p14/ 19ARF, but most intragenic pl6INK4A mutations do not disrupt p14/19ARF function ${ }^{70}$. Taniguchi, et al. reported that the lack of expression of p14/ 19ARF was found in diffuse, large B-cell lymphoma (DLBCL). Nevertheless, follicular lymphoma, myeloma and AML expressed p14/19ARF, and p16INK4A; p14/19ARF expression seemed to be affected differently among these malignancies ${ }^{71}$. These observations suggest that further studies of the 
INK4A locus and pl4/19ARF will be required to determine the role of these factors in tumor progression.

\section{PTEN}

The PTEN/MMAC1 gene located at 10q23.3 encodes a protein and is a novel TSG candidate with a domain homologous to protein phosphatases as well as a domain homologous to tensin, a cytoskeletal protein ${ }^{25,72}$. Phosphatase has been thought to be a potential $\mathrm{TSG}^{73}$. In contrast, some protein kinases have been identified as oncogenes ${ }^{74}$. The PTEN/MMACl gene is the first phosphatase to be identified as a TSG candidate, and mutations have been found frequently in various kinds of malignant tumors. Germ line mutations have been identified in Cowden disease patients, an autosomal dominant disorder associated with an increased risk of developing both benign and malignant tumors.

Various kinds of primary sporadic tumors show mutations in PTEN/MMAC1, including glioblastoma ${ }^{75}$, endometrial carcinoma ${ }^{76}$, and prostate can$\operatorname{cer}^{77}$. We examined 29 cases of primary NHL for mutations in the PTEN/MMACl gene. One case of DLBCL had an $11 \mathrm{bp}$ deletion, which contained the first $\mathrm{ATG}^{78}$. Missense mutations and homozygous deletions have also been reported in a small percentage of lymphoma cases ${ }^{79}$. These data indicate that alterations of the PTEN/MMACl gene are also involved in the pathogenesis of some NHL.

\section{SNF5/INI1}

The chromosomal deletions of $22 \mathrm{p} 11$, the region of the SNF5/INI1 gene locus, were frequently observed in lymphoid malignancy ${ }^{80}$. SNF5/INI1 has critical roles in chromatin remodeling, and is thought to be a candidate TSG, because germ line mutations of this gene have been reported in rhabdoid tumors of children ${ }^{81}$. We performed mutation analysis of this gene in primary lymphoid malignancies as well as in hematopoietic cell lines, and identified missense and nonsense mutations in one primary tumor and two cell lines ${ }^{82}$. The frequency of these genetic alterations was relatively low, but alteration of this gene in lymphoma has been suggested to have a role in the genesis of lymphoma.

\section{Chromosomal deletions, candidate regions for new TSG}

Karyotype analysis and other experiments have pointed to many chromosomal deletions in sporadic NHL, and some of them are reproducible. A complete understanding of the pathogenesis of NHL may require learning the clinical and biological meaning of such deletions. Recurrent chromosomal deletion may indicate the presence of candidate TSG in the deleted interval. So far, using the reverse-genetic approach, some candidate TSG have been cloned from chromosomal regions recurrently deleted in sporadic tumors ${ }^{25,26,27}$. The chromosomal deleted regions analyzed intensively in lymphoid malignancies are described below (Fig. 2).

\section{1. $6 p$}

LOH mapping is a method used widely for characterizing solid tumors, in which karyotyping is not practical, to identify genetic changes. In hematological malignancies it is easier to obtain sufficient information on chromosomal alterations by karyotyping, so allelotype studies rarely have been performed. Because of the presence of cryptic chromosomal deletions through karyotyping, allelotype studies could be another powerful method to evaluate genetic deletions. By a comprehensive allelotype study using 39 highly-informative microsatellite markers distributed among all autosomal chromosomes, we found frequent $\mathrm{LOH}$ at $6 \mathrm{p}$ in B-cell NHL ${ }^{83}$. The most frequent LOH occurred at polymorphic microsatellite marker D6S1721, where 9 of 18 of the informative cases $(50 \%)$ had allelic losses. Other regions with frequent $\mathrm{LOH}(>25 \%)$ were $1 \mathrm{q}, 3 \mathrm{p}$, and $6 \mathrm{q}$, respectively.

To identify the common deleted regions (CDR) of $6 \mathrm{p}$, we performed fine deletion mapping using 26 highly-polymorphic microsatellite markers on $6 \mathrm{p}$. LOH patterns indicated two CDR on 6p: one between D6S1721 and D6S260 (at 6p23-24), and the other between D6S265 and D6S291 (at 6p21). The genetic distance of both CDR was 6 cM. p21 (WAF1), which inhibits almost every kind of CDK, is located between D6S276 and D6S439 at 6p21.2. This interval was included in the CDR at $6 \mathrm{p} 21$. Thus, mutations of p21 (WAF1) were screened in NHL cases, yet no point mutations, other than polymorphisms, could be found in this gene.

Frequent allelic loss at $6 \mathrm{p}$ also has been reported in other tumors by allelotyping, such as renal cell 
chromosome 6

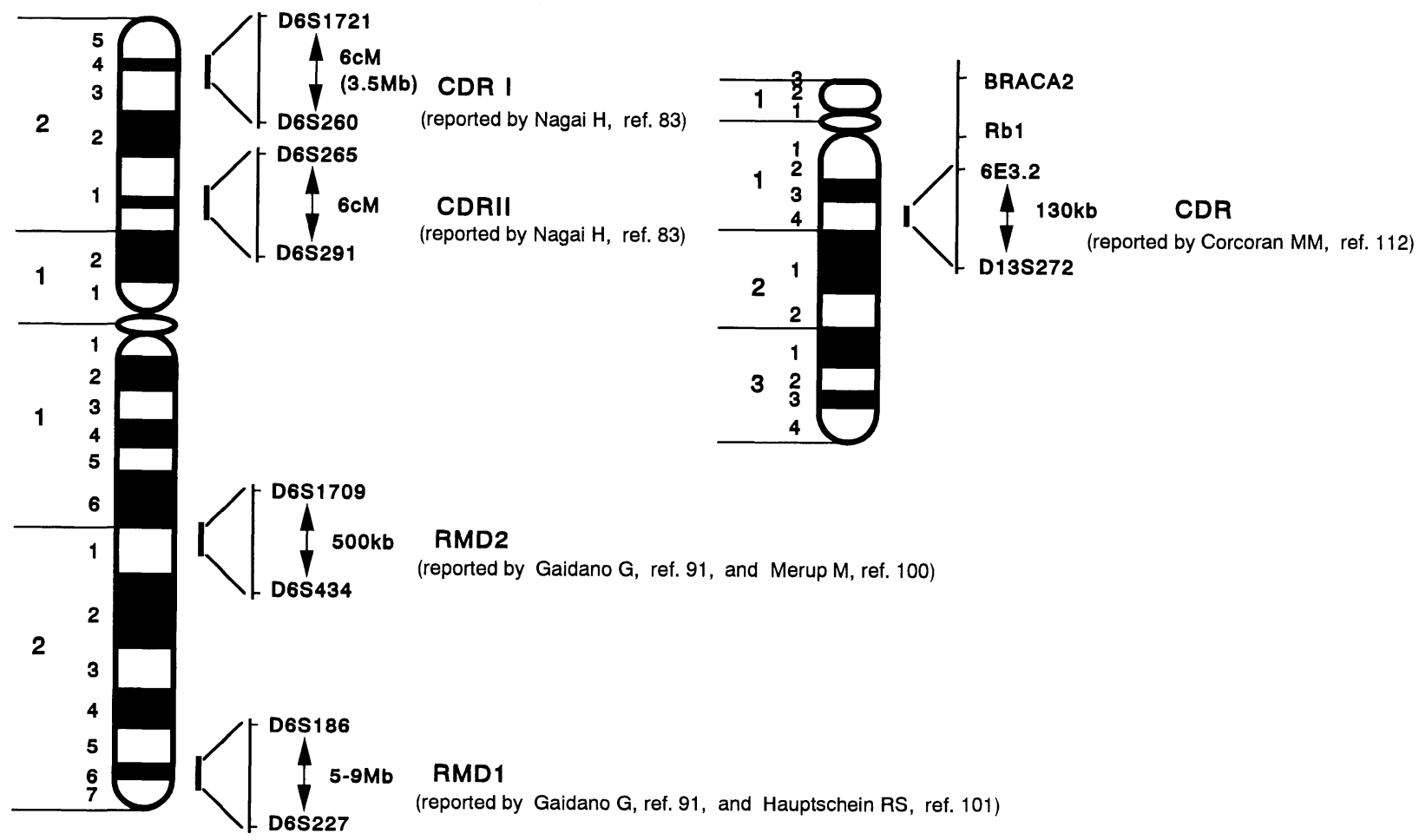

Fig. 2. Molecular delineation of chromosomal-deleted regions at chromosome 6 and 13. CDR : common deleted region, RMD : region of minimal molecular deletion, $\mathrm{cM}$ : centimorgan, $\mathrm{Mb}$ : megabase

carcinoma $^{84}$, cervical carcinoma ${ }^{85,86}$, and esophageal squamous cell carcinoma ${ }^{87}$. The data suggest that these two loci might harbor novel putative TSG responsible for the genesis of various tumors. Recently, we have cloned the CDR at 6p23-24 by yeast artificial chromosome (YAC) clones. The physical distance of this interval was approximated at $3.5 \mathrm{Mb}$ by this physical mapping ${ }^{83}$.

\section{2. $6 q$}

Karyotypic abnormalities of chromosome $6 \mathrm{q}$ represent one of the most frequent cytogenetic alterations observed in B-cell NHL ${ }^{2,88}$. Cytogenetic analysis using 459 specimens of NHL showed at least 3 loci that are commonly deleted on chromosome $6 q^{89}$. These regions were termed regions of minimal cytogenetic deletion (RCD), with RCD1 located at $6 q 25-q 27, R C D 2$ at $6 q 21$, and RCD3 at 6q23, respectively. The chromosomal deleted region at $6 \mathrm{q} 11-\mathrm{q} 21$ was also delineated using micro-FISH analysis ${ }^{90}$. One hundred twenty-six, out of 459, NHL cases (27.5\%) had structural abnormalities of chromosome 6 , and 94 (20.5\%) were chromosomal deletions.
Using a molecular biological technique, chromosome $6 \mathrm{q}$ was also proven to have 2 distinct regions of minimal molecular deletions (RMD) at 6q25-q27 (RMD1) and 6q21-q23 (RMD2), respectively ${ }^{91}$. RCD1 and 2, cited above, corresponded mostly to RMD1 and RMD2, respectively. The chromosomal deletions at 6q, especially in its distal region, were reported in various kinds of solid tumors, for example ovarian cancer ${ }^{92,93}$, hepatoma ${ }^{94}$, breast cancer ${ }^{95,96}$, and colon cancer ${ }^{97}$.

Chromosome-mediated transfer experiments in some tumor cell lines demonstrated that normal chromosome 6 could suppress their transformed phenotype ${ }^{98,99}$. Thus, the long arm of chromosome 6 has been thought to harbor a putative TSG. Finedeletion mapping of the commonly deleted regions of $6 q 21$, using lymphoblastic leukemia and NHL samples, narrowed RMD2 to an interval of less than $500 \mathrm{~kb}$ between D6S1709 and D6S434 ${ }^{100}$. Moreover, a physical mapping project on 6q26-27 confirmed that B-cell RMDl is located between D6S186 and D6S227. Its size was estimated as 5-9 $\mathrm{Mb}^{101}$.

The megabase sequencing project and other efforts are now concentrated on these regions, but no 
good candidate TSG have been cloned to date. AF6 $6^{102}$, located in RMD1, was also disrupted in some hematological malignancies by chromosomal translocation. And $\mathrm{BACH} 2^{103}$, located on $6 \mathrm{q} 15$, could reduce tumorigenic activity of some lymphoid cell lines. However, no somatic mutations in the coding region of these two genes have been found in NHL.

\section{3. $13 q$}

Cytogenetic analysis has shown that recurrent abnormalities of chromosome $13 \mathrm{q} 14$, including translocations and deletions, are the most common structural change in B-cell chronic lymphocytic leukemia $(\mathrm{CLL})^{104,105}$. This chromosomal deletion is the common genetic alteration in CLL. Molecular analysis also revealed $13 \mathrm{q}$ deletion in cases without karyotypic changes ${ }^{106}$. This region is very close to the RB1 locus, but the frequently deleted region was found around D13S25, telomeric to the RB1 locus ${ }^{107-109}$. This region was also reported to be deleted in B-cell NHL with a relatively high incidence $(25-50 \%)^{110,111}$.

The microsatellite marker showing the most frequent deletion at $13 q 14$ is D13S319110,112. It is located about $1 \mathrm{Mb}$ telomeric to the RB1 locus. This deleted region is actually a recurrent genetic alteration, and is thought to be a strong candidate locus for TSG. Nevertheless, inactivation of the RB1 gene seems to play a role in the malignant transformation of some lymphoid malignancies ${ }^{113}$. The deletion at 13 q 14 was analyzed for its possible correlation with the clinico-pathological features of NHL. This deletion represents an early chromosomal change and shows a preferential association with mantle cell lymphoma ${ }^{114}$. Several genes located on 13q14 were cloned as candidate $\mathrm{TSG}^{115}$, but these genes have not been confirmed as real TSG for lymphoid malignancies. A recent physical mapping project ${ }^{112}$ narrowed the common deleted region adjacent to D13S319 into a $130 \mathrm{~kb}$ interval. This interval is very small and thought to have been sequenced already. The candidate TSG, which is involved in pathogenesis of lymphoid malignancy, is expected to be cloned soon.

Another somatic deletion in CLL has been reported on chromosome 13q12.3 encompassing BRCA2, which is centromeric to the RB1 gene $\mathrm{e}^{116}$. However, BRACA2 might not be a candidate TSG for lymphoid malignancies, and there is a possibility of another TSG in this region.
As mentioned above, TSG other than oncogenes could have important roles in the development and progression of lymphoma. Comprehensive studies of TSG are crucial to understand the biological characteristics of malignant lymphoma. Some evidence has suggested that impairment of TSG, which affects the cellular response to DNA damage, might enhance susceptibility to chromosomal translocations ${ }^{117}$. Generally, specific chromosomal translocations are thought to represent early hits on genetic material, and will determine the subtype of lymphoid malignancies. Alterations of TSG, a later event, will affect tumor progression. It is very important to identify poor risk patients to improve the outcome of treatment for malignant lymphoma. A complete database of TSG alterations in lymphoma and a full understanding of the clinical features of each tumor subtype are indispensable to improving the management of malignant lymphoma and the development of new strategies for treatment.

Genome sequencing will be completed early in this century: and almost all genes will be cloned and their precise chromosomal location will be determined. At this stage there is an urgent need to provide researchers with all possible information on the locations of unique chromosomal alterations, especially deletions, to identify the tumor suppressor genes. Cloning a disease-responsible gene using molecular and cytogenetic techniques will open the door to post-genome medicine.

\section{REFERENCES}

1 Rowley JD: Recurring chromosome abnormalities in leukemia and lymphoma. Semin Hematol 27 : 122-136, 1990

2 Offit K, Wong G, Filippa DA, Tao Y, Chaganti RSK : Cytogenetic analysis of 434 consecutively ascertained specimens of non-Hodgkin's lymphoma: clinical correlations. Blood 77 : 1508-1515, 1991

3 Tsujimoto Y, Yunis J, Onorato-Showe L, Erikson J, Nowell PC, Croce CM : Molecular cloning of the chromosomal breakpoint of B-cell lymphomas and leukemias with $\mathrm{t}(11 ; 14)$ chromosome translocation. Science 224: 1403-1406, 1984

4 Motokura T, Bloom T, Kim HG, Juppner H, Ruderman JV, Kronenberg HM, Arnold A: A novel cyclin encoded by a bcll-linked candidate oncogene. Nature 350: 512-515, 1991

5 Tsujimoto Y, Cossman J, Jaffe E, Croce CM : Involvement of the bcl-2 gene in human follicular lymphoma. Science 228: 1440-1443, 1995 
6 Baron BW, Nucifora G, MacCabe N, Espinosa R 3rd, LeBeau MM, McKeithan TW : Identification of the gene associated with the recurring chromosomal translocations $\mathrm{t}(3 ; 14)$ (q27; q32) and $\mathrm{t}(3 ; 22)$ (q27; q11) in B-cell lymphomas. Proc Natl Acad Sci USA 90: 5262-5266, 1993

7 LoCoco F, Ye BH, Lista F, Corradini P, Offit K, Knowles DM, Chaganti RSK, Dalla-Favera R: Rearrangements of the BCL6 gene in diffuse large cell non-Hodgkin's lymphoma. Blood 83: 17571759, 1994

8 Willis TG, Jadayel DM, Du MQ, Peng H, Perry AR, Abdul-Rauf M, Price H, Karran L, Majekodunmi O, Wlodarska I, Pan L, Crook T, Hamoudi R, Isaacson PG, Dyer MJS: Bcl10 is involved in $\mathrm{t}(1 ; 14)(\mathrm{p} 22 ; \mathrm{q} 32)$ of MALT B cell lymphoma and mutated in multiple tumor types. Cell 96: 35-45, 1999.

9 Morris SW, Kirstein MN, Valentine MB, Dittmer KG, Shapiro DN, Saltman DL, Look AT : Fusion of a kinase gene, ALK, to a nucleolar protein gene, NPM, in non-Hodgkin's lymphoma. Science 263 : 1281-1284, 1994.

10 Akagi T, Motegi M, Tamura A, Suzuki R, Hosokawa Y, Suzuki H, Ota H, Nakamura S, Morishima Y, Taniwaki M, Seto M : A novel gene, MALT1 at $18 \mathrm{q} 21$, is involved in $\mathrm{t}(11 ; 18)(\mathrm{q} 21 ; \mathrm{q} 21)$ found in low-grade B-cell lymphoma of mucosaassociated lymphoid tissue. Oncogene 18: 57855794, 1999

11 Dierlamm J, Baens M, Wlodarska I, StefanovaOuzounova M, Hernandez JM, Hossfeld DK, De Wolf-Peeters C, Hagemeijer A, Van den Berghe H, Marynen $\mathrm{P}$ : The apoptosis inhibitor gene API2 and a novel $18 \mathrm{q}$ gene, MLT, are recurrently rearranged in the $\mathrm{t}(11 ; 18)(\mathrm{q} 21 ; \mathrm{q} 21)$ associated with mucosa-associated lymphoid tissue lymphomas. Blood 93: 3601-3609, 1999

12 Knudson AG: Mutation and cancer: Statistical study of retinoblastoma. Proc Natl Acad Sci USA $68: 820-823,1971$

13 Friend SH, Bernards R, Rogelj S, Weinberg RA, Rapaport JM, Albert DM, Dryja TP: A human DNA segment with properties of the gene that predisposes to retinoblastoma and osteosarcoma. Nature 323: 643-646, 1986

14 Call KM, Glaser T, Ito CY, Buckler AJ, Pelletier J, Haber DA, Rose EA, Kral A, Yeger H, Lewis $\mathrm{WH}$, Jones C, Housman DE: Isolation and characterization of a zinc finger polypeptide gene at the human chromosome 11 Wilms' tumor locus. Cell $60: 509-520,1990$

15 Malkin D, Li FP, Strong LC, Fraumeni JF Jr, Nelson CE, Kim DH, Kassel J, Gryka MA, Bischoff FZ, Tainsky MA, Friend SH: Germ line p53 mutations in a familial syndrome of breast cancer, sarcomas, and other neoplasms. Science $250: 1233-1238,1990$

16 Srivastava S, Zou ZQ, Pirollo K, Blattner W, Chang EH : Germ-line transmission of a mutated p53 gene in a cancer-prone family with LiFraumeni syndrome. Nature 348: 747-749, 1990

17 Nishisho I, Nakamura Y, Miyoshi Y, Miki Y, Ando H, Horii A, Koyama K, Utsunomiya J, Baba S, Hedge P, Markham A, Krush AJ, Petersen G, Hamilton SR, Nilbert MC, Levy DB, Bryan TM, Preisinger AC, Smith KJ, Su L-K, Kinzler KW, Vogelstein B: Mutations of chromosome 5q21 genes in FAP and colorectal cancer patients. Science $253: 665-669,1991$

18 Ichikawa A, Hotta T, Takagi N, Tsushita K, Kinoshita T, Nagai H, Murakami Y, Hayashi K, Saito $\mathrm{H}$ : Mutations of p53 gene and their relation to disease progression in B-cell lymphoma. Blood 79: 2701-2709, 1992

19 Nagai H, Kinoshita T, Imamura J, Murakami Y, Hayashi K, Mukai K, Ikeda S, Tobinai K, Saito H, Shimoyama M, Shimotohono K: Genetic alteration of p53 in some' patients with adult T-cell leukemia. Jpn J Cancer Res 82: 1421-1427, 1991

20 Uchida T, Watanabe T, Kinoshita T, Murate T, Saito H, Hotta $T$ : Mutational Analysis of the CDKN2 (MST1/pl6ink4A) gene in primary B-cell lymphomas. Blood 86: 2724-2731, 1995

21 Ichikawa A, Kinoshita T, Watanabe T, Kato H, Nagai H, Tsushita K, Saito H, Hotta T: Mutations of the p53 gene as a prognostic factor in aggressive B-cell lymphoma. N Engl J Med 337 : 529-534, 1997

22 Nigro JM, Baker SJ, Preisinger AC, Jessup JM, Hostetter R, Cleary K, Bigner SH, Davidson N, Baylin S, Devilee P, Glover T, Collins FS, Weston A, Modali R, Harris CC, Vogelstein B : Mutations in the p53 gene occur in diverse human tumor types. Nature 342: 705-708, 1989

23 Hainaut P, Hernandez T, Robinson A, RodriguezTome P, Flores T, Hollstein M, Harris CC, Montesano R: IARC Database of p53 gene mutations in human tumors and cell lines: updated complication, revised formats and new visualization tools. Nucleic Acids Res 26: 205-213, 1998

24 Ogawa S, Hirano N, Sato N, Takahashi T, Hangaishi A, Tanaka K, Kurokawa M, Tanaka T, Yazaki Y, Mitani K, Hirai H: Homozygous loss of the cyclin-dependent kinase 4 inhibitor (p16) gene in human leukemias. Blood 84: 2431-2435, 1994

25 Ohta M, Inoue H, Cotticelli MG, Kastury K, Baffa R, Palazzo J, Siprashvili Z, Mori M, McCue P, Druck T, Croce CM, Huebner $\mathrm{K}$ : The FHIT gene, spanning the chromosome 3p14.2 fragile site 
and renal carcinoma-associated $\mathrm{t}(3 ; 8)$ breakpoint, is abnormal in digestive tract cancers. Cell 84 : 587-597, 1996

26 Hahn SA, Schutte M, Hoque TMS, Moskaluk CA, da Costa LT, Rozenblum E, Weinstein CL, Fischer A, Yeo CJ, Hruban RH, Kern SE : DPC4, a candidate tumor suppressor gene at human chromosome 18q21.1. Science 271: 350-353, 1996

27 Li J, Yen C, Liaw D, Podsypanina K, Bose S, Wang SI, Puc J, Miliaresis C, Rodgers L, McCombie R, Bigner SH, Giovanella BC, Ittmann $\mathrm{M}$, Tycko B, Hibshoosh H, Wigler MH, Parsons R: $P T E N$, a putative protein phosphatase gene mutated in human brain, breast, and prostate cancer. Science 275: 1943-1947, 1997

28 Merlo A, Herman JG, Mao L, Lee DJ, Gabrielson E, Burger PC, Baylin SB, Sidransky D : 5' CpG island methylation is associated with transcriptional silencing of the tumor suppressor p16/ CDKN2/MTS1 in human cancers. Nat Med 1: 686-692, 1995

29 Herman JG, Graff JR, Myohanen S, Nelkin BD, Baylin SB: Methylation-specific PCR: a novel PCR assay for methylation status of $\mathrm{CPG}$ islands. Proc Natl Acad Sci USA 93: 9821-9826, 1996

30 Herman JG, Jen J, Merlo A, Baylin SB : Hypermethylation-associated inactivation indicates a tumor suppressor role for p15INK4B. Cancer Res 56: 722-726, 1996

31 Uchida T, Kinoshita T, Nagai H, Nakahara Y, Saito H, Hotta T, Murate T: Hypermethylation of the p15INK4B gene in myelodysplastic syndromes. Blood 90 : 1403-1409, 1997

32 Banin S, Moyal L, Shieh S-Y, Taya Y, Anderson CW, Chessa L, Smorodinsky NI, Prives C, Reiss Y, Shiloh Y, Ziv Y : Enhanced phosphorylation of p53 by ATM in response to DNA damage. Science 281: 1674-1677, 1998

33 Harper JW, Adami GR, Wei N, Keyomarsi K, Elledge SJ : The p21 Cdk-interacting protein Cipl is a potent inhibitor of Gl cyclin-dependent kinases. Cell 75: 805-816, 1993

34 El-Deiry WS, Tokino T, Velculescu VE, Levy DB, Parsons R, Trent JM, Lin D, Mercer E, Kinzler $\mathrm{KW}$, Vogelstein B: WAF1, a potential mediator of p53 tumor suppression. Cell 75: 817-825, 1993

35 Polyak K, Xia Y, Zweier JL, Kinzler KW, Vogelstein B: A model for p53-induced apoptosis. Nature 389: 300-305, 1997

36 Oda K, Arakawa H, Tanaka T, Matsuda K, Tanikawa C, Mori $\mathrm{T}$, Nishimori $\mathrm{H}$, Tamai $\mathrm{K}$, Tokino T, Nakamura Y, Taya Y: p53AIP1, a potential mediator of p53-dependent apoptosis, and its regulation by Ser-46-phosphorylated $\mathrm{p} 53$. Cell 102: 849-62, 2000
37 Tanaka H, Arakawa H, Yamaguchi T, Shiraishi K, Fukuda S, Matsui K, Takei Y, Nakamura Y : A ribonucleotide reductase gene involved in a p53-dependent cell-cycle checkpoint for DNA damage. Nature 404: 42-9, 2000

38 Gaidano G, Ballerini P, Gong JZ, Inghirami G, Neri A, Newcomb EW, Magrath IT, Knowles DM, Dalla-Favera $R$ : p53 mutation in human lymphoid malignancies : association with Burkitt's lymphoma and chronic lymphocytic leukemia. Proc Natl Acad Sci U S A 88: 5413-5417, 1991

39 Sander CA, Yano T, Clark HM, Harris C, Longo DL, Jaffe ES, Raffeld M : p53 mutation is associated with progression in follicular lymphoma. Blood 82 : 1994-2004, 1993

40 Mitsudomi T, Oyama T, Kusano T, Osaki T, Nakanishi R, Shirakusa T: Mutations of the p53 gene as a predictor of poor prognosis in patients with non-small-cell lung cancer. J Natl Cancer Inst 85 : 2018-2023, 1993

41 Mazars R, Spinardi L, BenCheikh M, SimonyLafontaine J, Jeanteur P, Theillet C: p53 mutations occur in aggressive breast cancer. Cancer Res 52: 3918-3923, 1992

42 The international Non-Hodgkin's Lymphoma Prognostic Factors Project: A predictive model for aggressive non-Hodgkin's lymphoma. N Engl J Med 329: 987-994, 1993

43 Kaghad $\mathrm{M}$, Bonnet $\mathrm{H}$, Yang A, Creancier L, Biscan JC, Valent A, Minty A, Chalon P, Lelias JM, Dumont X, Ferrara P, McKeon F, Caput D : Monoallelically expressed gene related p53 at $1 \mathrm{p} 36$, a region frequently deleted in neuroblastoma and other human cancers. Cell 90, 809-819, 1997

44 Yang HW, Piao HY, Chen YZ, Takita J, Kobayashi M, Taniwaki M, Hashizume K, Hanada R, Yamamoto K, Taki T, Bessho F, Yanagisawa M, Hayashi $Y$ : The p73 gene is less involved in the development but involved in the progression of neuroblastoma. Int J Mol Med 5: 379-384, 2000

45 Kawano S, Miller CW, Gombart AF, Bartram CR, Matsuo Y, Asou H, Sakashita A, Said J, Tatsumi E, Koeffler HP: Loss of p73 gene expression in leukemias/lymphomas due to hypermethylation. Blood 94: 1113-1120, 1999

46 Savitsky K, Bar-Shira A, Gilad S, Rotman G, Ziv Y, Vanagaite L, Tagle DA, Smith S, Uziel T, Sfez S, Ashkenazi M, Pecker I, Frydman M, Harnik R, Patanjali SR, Simmons A, Clines GA, Sartiel A, Gatti RA, Chessa L, Sanal O, Lavin MF, Jaspers NGL, Taylor MR, Arlett CF, Miki T, Weissman SM, Lovett M, Collins FC, Shiloh Y: A single ataxia telangiectasia gene with a product similar to PI-3 kinase. Science 268 : 1749-1753, 1995.

47 Stilgenbauer S, Schaffner C, Litterst A, Liebisch P, 
Gilad S, Bar-Shira A, James MR, Lichter P, Dohner $\mathrm{H}$ : Biallelic mutations in the ATM gene in T-prolymphocytic leukemia. Nat Med 3: 11551159,1997

48 Vorechovsky I, Luo L, Dyer MJ, Catovsky D, Amlot PL, Yaxley JC, Foroni L, Hammarstrom L, Webster AD, Yuille MA: Clustering of missense mutations in the ataxia-telangiectasia gene in a sporadic T-cell leukemia. Nat Genet 17: 96-99, 1997

49 Schaffner C, Idler I, Stilgenbauer S, Dohner H, Lichter P : Mantle cell lymphoma is characterized by inactivation of the ATM gene. Proc Nat Acad Sci USA 97: 2773-2778, 2000.

50 Carney JP, Maser RS, Olivares H, Davis EM, Le Beau M, Yates JR III, Hays L, Morgan WF, Petrini JHJ: The hMrell/hRad50 protein complex and Nijmegen breakage syndrome : linkage of double-strand break repair to the cellular DNA damage response. Cell 93: 477-486, 1998

51 Diaz MO, Ziemin S, Le Beau MM, Pitha P, Smith SD, Chilcote RR, Rowley JD: Homozygous deletion of the alpha- and beta 1-interferon genes in human leukemia and derived cell lines. Proc Natl Acad Sci USA 85: 5259-5256, 1988

52 Diaz OM, Rubin CM, Harden A, Ziemen S, Larson RA, Le Beau MM, Rowly JD: Deletions of interferon genes in acute lymphoblastic leukemia. N Engl J Med 332: 77-82, 1990

53 Serrano M, Hannon GJ, Beach D: A new regulatory motif in cell cycle control causing specific inhibition of cyclin D/CDK4. Nature 366 : 704-707, 1993

54 Kamb A, Gruis NA, Weaver-Feldhaus J, Liu Q, Harhsman K, Tavtigian SV, Stockert E, Day RS III, Johnson BE, Skolnick MH : A cell cycle regulator potentially involved in genesis of many tumor types. Science 264 : 436-440, 1994

55 Nobori T, Miura K, Wu DJ, Lois A, Takabayashi $\mathrm{K}$, Carson DA : Deletions of the cyclin dependent kinase-4 inhibitor gene in multiple human cancers. Nature 368: 753-756, 1994

56 Hannon GJ, Beach D: p15INK4B is a potential effecter of TGF- $\beta$ induced cell cycle arrest. Nature 371: 257-261, 1994

57 Hebert J, Cayuela JM, Berkeley J, Sigaux F: Candidate tumor suppressor genes MTS1 (p16INK4A) and MTS2 (p15INK4B) display frequent homozygous deletions in primary cells from T- but not from B-cell lineage acute lymphoblastic leukemias. Blood 84 : 4038-4044, 1994

58 Koduru PRK, Zariwala M, Soni M, Gong JZ, Xiong Y, Broome JD: Deletoin of cyclindependent kinase 4 inhibitor genes p15 and p16 in non-Hodgkin's lymphoma. Blood 86 : 2900-2905.
1995

59 Dreyling MH, Bullinger L, Ott G, Stilgenbauer S, Muller-Hermelink HK, Bentz M, Hiddemann W, Dohner $\mathrm{H}$ : Alteration of the cyclin Dl/pl6-pRb pathway in mantle cell lymphoma. Cancer Res 57 : 4608-4614, 1997

60 Uchida T, Kinoshita T, Murate T, Saito H, Hotta T: CDKN2 (MTS1/p16INK4A) gene alterations in adult $\mathrm{T}$-cell leukemia/lymphoma. Leukemia \& Lymphoma 29 : 27-35, 1998

61 Elenitoba-Johnson KSJ, Gascoyne RD, Lim MS, Chhanabai M, Jaffe ES, Raffeld M : Homozygous deletions at chromosome 9p21 involving p16 and p15 are associated with histologic progression in follicle center lymphoma. Blood 91: 4677-4685, 1998

62 Pinyol M, Hernandez L, Cazorla M, Balbin M, Jares P, Fernandez PL, Montserrat E, Cardesa A, Lopez-Otin C, Campo E: Deletions and loss of expression of p16INK4a and p21Wafl genes are associated with aggressive variants of mantle cell lymphomas. Blood 89: 272-280, 1997

63 Herman JG, Civin CL, Issa JPJ, Collector MI, Sharkis SJ, Baylin SB : Distinct patterns of inactivation of p15INK4B and p16INK4A characterize major types of hematological malignancies. Cancer Res 57: 837-841, 1997

64 Iravani M, Dhat R, Price CM : Methylation of multi tumor suppressor gene -2 (MTS2, CDKN1, p15 (INK4B)) in childhood acute lymphoblastic leukemia. Oncogene 15: 2609-2614, 1997

65 Batova A, Diccianni MB, Yu CJ, Nobori T, Link MP, Pullen J, Yu AL: Frequent and selective methylation of p15 and deletion of both p15 and p16 in T-cell acute lymphoblastic leukemia. Cancer Res 57: 832-836, 1997

$66 \mathrm{Ng}$ MHL, Chung YF, Lo KW, Wickham NWR, Lee JCK, Huang DP : Frequent hypermethylation of p16 and p15 genes in multiple myeloma. Blood 89 : 2500-2506, 1997

67 Baur AS, Shaw P, Burri N, Delacretaz F, Bosman FT, Chaubert P: Frequent methylation silencing of p15INK4B (MTS2) and pl6INK4A (MTS1) in B-cell and t-cell lymphomas. Blood 94: 17731781, 1999

68 Quelle DE, Zindy F, Ashmun RA, Sherr CJ : Alternative reading frames of the INK4a tumor suppressor gene encode two unrelated proteins capable of inducing cell cycle arrest. Cell 83 : 9931000,1995

69 Zhang Y, Xiong Y, Yarbrough WG: ARF promotes MDM2 degradation and stabilizes p53: ARF-INK4a locus deletion impairs both the $\mathrm{Rb}$ and p53 tumor suppression pathways. Cell 92 : 725-734, 1998 
70 Quelle DE, Cheng M, Ashmun RA, Sherr CJ : Cancer-associated mutations at the INK4a locus cancel cell cycle arrest by p16INK4a but not by the alternative reading frame protein p19ARF. Proc Natl Acad Sci USA 94. 669-673, 1997

71 Taniguchi T, Chikatsu N, Takahashi S, Fujita A, Uchimaru K, Asano S, Fujita T, Motokura T: Expression of pl6INK4A and pl4ARF in hematological malignancies. Leukemia 13. 17601769, 1999

72 Steck PA, Pershouse MA, Jasser SA, Yung WKA, Lin $\mathrm{H}$, Ligon AH, Langford LA, Baumgard ML, Hattier T, Davis T, Frye C, Hu R, Swedlund B, Teng DHF, Tavtigian SV: Identification of a candidate tumor suppressor gene, MMACl, at chromosome 10q23.3 that is mutated in multiple advanced cancer. Nat Genet 15: 356-362, 1997

73 LaForgia S, Morse B, Levy J, Barnea G, Cannizzaro LA, Li F, Nowell PC, Boghosian-Sell L, Glick J, Weston A. Harris CC, Drabkin H, Patterson $\mathrm{D}$, Croce $\mathrm{CM}$, Schlessinger $\mathrm{J}$, Huebner $\mathrm{K}$ : Receptor protein-tyrosine phosphatase gamma is a candidate tumor suppressor gene at human chromosome region $3 \mathrm{p} 21$. Proc Natl Acad Sci USA 88 : 5036-5040, 1991

74 Hunter $\mathrm{T}$ : The functions of oncogene products. Prog Clin Biol Res 288 : 25-34, 1989

75 Wang SI, Puc J, Li J, Bruce JN, Cairns P, Sidransky D, Parsons R: Somatic mutations of PTEN in glioblastoma multiforme. Cancer Res 57: 41834186, 1997

76 Guldberg P, thor Straten P, Birck A, Ahrenkiel V, Kirkin AF, Zeuthen $\mathbf{J}$ : Disruption of the MMAC1/PTEN gene by deletion or mutation is a frequent event in malignant melanoma. Cancer Res 57 : 3660-3663, 1997

77 Tashiro H, Blazes MS, Wu R, Cho KR, Bose S, Wang SI, Li J, Parsons R, Ellenson LH: Mutations in PTEN are frequent in endometrial carcinoma but rare in other common gynecological malignancies. Cancer Res 57: 3935-3940, 1997

78 Nakahara Y, Nagai H, Kinoshita T, Uchida T, Hatano S, Murate T, Saito H : Mutational analysis of the PTEN/MMACl gene in non-Hodgkin's lymphoma. Leukemia 12: 1277-1280, 1998

79 Sakai A, Thieblemont C, Wellmann A, Jaffe ES, Raffeld M : PTEN gene alterations in lymphoid neoplasms. Blood 92: 3410-3415, 1998

80 Calasanz MJ, Cigudosa JC, Odero MD, Ferreira C, Ardanaz MT, Fraile A, Carrasco JL, Sole F, Cuesta B, Gullon A : Cytogenetic analysis of 280 patients with multiple myeloma and related disorders: primary breakpoints and clinical correlations. Genes Chromosomes Cancer 18: 84-93, 1997
81 Versteege I, Sevenet N, Lange J, Rousseau-Merck $\mathrm{MF}$, Ambros $\mathrm{P}$, Handgretinger $\mathrm{R}$, Aurias $\mathrm{A}$, Delattre O : Truncating mutations of hSNF5/INI1 in aggressive pediatric cancer. Nature 394: 203206, 1998

82 Yuge M, Nagai H, Uchida T, Murate T, Hayashi Y, Hotta T, Saito H, Kinoshita T. HSNF5/INI1 gene mutations in lymphoid malignancy. Cancer Genet Cytogenet 122: 37-42, 2000

83 Nagai H, Kinoshita T, Suzuki H, Hatano S, Murate T, Saito H : Identification and mapping of novel tumor suppressor loci on $6 \mathrm{p}$ in diffuse large B-cell non-Hodgkin's lymphoma. Genes Chromosomes Cancer 25 : 277-283, 1999

84 Schwerdtle RF, Storkel S, Neuhaus C, Brauch H, Weidt E, Brenner W, Hohenfeller C, Huber C, Decker HJ : Allelic loss at chromosome 1p, 2p, 6p, $10 p, 13 q, 17 p$, and $21 q$ significantly correlated with the chromophobe subtype of renal cell carcinoma. Cancer Res 56: 2927-2930, 1996

85 Mitra AB, Murty VV, Li RG, Pratap M, Luthra UK, Chaganti RSK : Allelotype analysis of cervical carcinoma. Cancer Res 54: 4481-4487, 1994

86 Mullokandov MR, Kholodilov NG, Atkin NB, Burk RD, Johnson AB, Kinger HP : Genetic alterations in cervical carcinoma: losses of chromosome heterozygosity and human papilloma virus tumor status. Cancer Res 56: 197-205, 1996

87 Shibagaki I, Shimada Y, Wagata T, Ikenaga M, Imamura M, Ishizaki $\mathrm{K}$ : Allelotype analysis of esophageal squamous cell carcinoma. Cancer Res 54 : 2996-3000, 1994

88 Johansson SC, Mertens F, Mitelman F : Cytogenetic deletion maps of hematologic neoplasms: Circumstantial evidence for tumor suppressor loci. Gene Chromosomes Cancer 8: 205218, 1993

89 Offit K, Parsa NZ, Gaidano G, Filippa DA, Louie D, Pan D, Jhanwar SC, Dalla-Favera R, Chaganti RSK : $6 \mathrm{q}$ deletions define distinct clinicopathologic subsets of non-Hodgkin's lymphoma. Blood 82 : 2157-2162, 1993

90 Guan XY, Horsman D, Zhang HE, Parsa NZ, Meltzer PS, Trent JM: Localization by chromosome microdissection of a recurrent breakpoint region on chromosome 6 in human B-cell lymphoma. Blood 88: 1418-1422, 1996

91 Gaidano G, Hauptschein RS, Parsa NZ, Offit K, Rao PH, Lenoir G, Knowles DM, Chaganti RSK, Dalla-Favera $\mathrm{R}$ : Deletions involving two distinct regions of $6 \mathrm{q}$ in B-cell non-Hodgkin's lymphoma. Blood 80: 1781-1787, 1992

92 Saito S, Sirahama S, Matsushima M, Suzuki M, Sagae S, Kudo R, Saito J, Noda K, Nakamura Y : Definition of a commonly deleted region in ovar- 
ian cancers to a $300-\mathrm{kb}$ segment of chromosome 6q27. Cancer Res 56: 5586-5589, 1996

93 Cooke IE, Shelling AN, LeMeuth VG, Charnock ML, Ganesan TS: Allelic loss on chromosome arm $6 \mathrm{q}$ and fine mapping of the region at $6 \mathrm{q} 27$ in epithelial ovarian cancer. Genes Chromosomes Cancer 15: 223-233, 1996

94 De Souza AT, Hankins GR, Washington MK, Fine RL, Orton TC, Jirtle RL: Frequent loss of heterozygosity on $6 \mathrm{q}$ at the mannose 6-phosphate/ insulin-like growth factor II receptor locus in human hepatocellular tumors. Oncogene 10 : 1725-1729, 1995

95 Devilee $\mathrm{P}$, van Vliet $\mathrm{M}$, van Sloun $\mathrm{P}$, Kuipers Dijkshoorn N, Hermans J, Pearson PL, Cornelisse CJ : Allelotype of human breast carcinoma: A second major site for loss of heterozygosity is on chromosome 6q. Oncogene 6: 1705-1711, 1991

96 Theile M, Seitz S, Arnold W, Jandrig B, Frege R, Schlag PM, Haensch W, Guski H, Winzer KJ, Barrett JC, Scherneck S: A defined chromosome 6q fragment (at D6S310) harbors a putative tumor suppressor gene for breast cancer. Oncogene 13 : 677-685, 1996

97 Honchel R, McDonnell S, Schaid DJ, Thibodeau $\mathrm{SN}$ : Tumor necrosis factor-alpha allelic frequency and chromosome 6 allelic imbalance in patients with colorectal cancer. Cancer Res 56: 145-149, 1996

98 Trent JM, Stanbridge EJ, McBride HL, Meese EU, Casey G, Araujo DE, Witkowski CM, Nagle RB : Tumorgenicity in human melanoma cell lines controlled but introduction of human chromosome 6. Science 247: 568-571, 1990

99 Negrini M, Sabbioni S, Possati L, Ratten S, Corallini A, Barbanti-Brodano G, Croce CM : Suppression of tumorgenicity of breast cancer cells by microcell-mediated chromosome transfer: Studies on chromosomes 6 and 11. Cancer Res 54:13311336, 1994

100 Merup M, Moreno TC, Heyman M, Ronnberg K, Grander D, Detlofsson R, Rassol O, Liu Y, Soderhall S, Julliusson G, Gahrton G, Einhorn S : 6q deletion in acute lymphoblastic leukemia and non-Hodgkin's lymphomas. Blood 91 : 3397-3400, 1998

101 Hauptschein RS, Gamberi B, Rao PH, Frigeri F, Scotto L, Venkatrai VS, Gaidano G, Rutner T, Edwards YH, Chaganti RSK, Dalla-Favera R : Cloning and mapping of human chromosome 6q26-q27 deleted in B-cell non-Hodgkin lymphoma and multiple tumor types. Genomics 50 : 170-186, 1998

102 Prasad R, Gu Y, Alder H, Nakamura T, Canaani O, Saito H, Huebner K, Gale RP, Nowell PC,
Kuriyama K, Miyazaki Y, Croce CM, Canaani E : Cloning of the ALL-1 fusion partner, the AF-6 gene, involved in acute myeloid leukemias with the $\mathrm{t}(6 ; 11)$ chromosome translocation. Cancer Res. 53: 5624-5628, 1993.

103 Sasaki S, Ito E, Toki T, Maekawa T, Kanezaki R, Umenai $\mathrm{T}$, Muto A, Nagai $\mathrm{H}$, Kinoshita $\mathrm{T}$, Yamamoto M, Inazawa J, Taketo M, Nakahata T, Igarashi $\mathrm{K}$, Yokayama $\mathrm{M}$ : Cloning and expression of human $\mathrm{B}$ cell-specific transcription factor BACH2 mapped to chromosome $6 \mathrm{q} 15$. Oncogene 19: 3739-3749, 2000

104 Fitchett M, Griffiths MJ, Oscier DG, Johnson S, Seabright $\mathrm{M}$ : Chromosome abnormalities involving band $13 \mathrm{q} 14$ in hematologic malignancies. Cancer Genet Cytogenet 24: 143-150, 1987

105 Juliusson G, Oscier DG, Fitchett M, Ross FM, Stockdill G, Mackie MJ, Parker AC, Castoldi GL, Guneo A, Knuutila S, Elonen E, Gahrton G: Prognostic subgroups in B-cell chronic lymphocytic leukemia defined by specific chromosomal abnormalities. New Engl J Med 323: 720-724, 1990

106 Liu Y, Grander D, Soderhall S, Julisson G, Gahrton G, Einhorn ES : Retinoblastoma gene deletions in B-cell chronic lymphocytic leukemia. Genes Chromosom Cancer 4: 250-256, 1992

106 Liu Y, Szekely L, Grander D, Sonderhall S, Julisson G, Gahton S, Linder S, Einhorn S: Chronic lymphocytic leukemia cells with allelic deletions at 13 q14 commonly have on intact RBl gene: evidence for a role of an adjacent locus. Proc Natl Acad Sci USA 90: 8697-8701, 1993

108 Brown AG, Ross FM, Dunne EM, Steel CM, Weir-Thompson EM : Evidence for a new tumor suppressor locus (DBM) in human B-cell neoplasia telomeric to the retinoblastoma gene. Nat Genet 3 : 67-72, 1993

109 Chapman RM, Corcoran MM, Gardiner A, Hawthorn LA, Cowell JK, Oscier DG : Frequent homozygous deletions of the D13S25 locus in chromosome region $13 \mathrm{q} 14$ defines the location of a gene critical leukemogenesis in chronic B-cell lymphocytic leukemia. Oncogene 9: 1289-1293, 1994

110 Liu Y, Hermanson M, Grander D, Merup M, Wu X, Heyma M, Rasool O, Juliusson G, Gahrton G, Detlofsson R, Nikiforova N, Buys C, Sonderhall S, Yankovsky N, Zabarovsky E, Einhorn S: 13q deletions in lymphoid malignancies. Blood 86 : 1911-1915, 1995

111 Wada M, Okamura T, Okada M, Teramura M, Masuda M, Motoji T, Mizoguchi H : Delineation of the frequently deleted region on chromosome arm 13q in B-cell non-Hodgkin's lymphoma. Int J 
Hematol 71: 159-166, 2000

112 Corcoran MM, Rasool O, Liu Y, Iyengar A, Grander D, Ibbotson RE, Merup M, Wu X, Brodyansky V, Gardiner AC, Juliusson G, Chapman RM, Ivanova G, Tiller M, Gahrton G, Yankovsky N, Zabarovsky E, Oscier DG, Einhorn S : Detailed molecular delineation of 13q14.3 loss in B-cell chronic lymphocytic leukemia. Blood 91 : 1382-1390, 1998

113 Chen YC, Chen PJ, Yeh SH, Tien HF, Wang CH, Tang JL, Hong RL: Deletion of the human retinoblastoma gene in primary leukemias. Blood. 76 : 2060-2064, 1990

114 Cuneo A, Bigoni R, Rigolin GM, Roberti MG, Bardi A, Campioni D, Minotto C, Agostini P, Milani R, Bullrich F, Negrini M, Croce CM, Castoldi G: 13q14 deletion in non-Hodgkin's lymphoma: correlation with clinicopathologic features. Haematologica 84 : 589-593, 1999

115 Liu Y, Corcoran M, Rasool O, Ivanova G, Ibbot- son R, Grander D, Iyengar A, Baranova A, Kashuba V, Merup M, Wu X, Gardiner A, Mullenbach R, Poltaraus A, Hultstrom AL, Juliusson G, Chapman R, Tiller M, Cotter F, Gahrton G, Yankovsky N, Zabarovsky E, Einhorn S, Oscier D : Cloning of two candidate tumor suppressor genes within a $10 \mathrm{~kb}$ region on chromosome $13 \mathrm{ql}$, frequently deleted in chronic lymphocytic leukemia. Oncogene 15: 2463-2473, 1997

116 Gracia-Marco JA, Caldas C, Price CM, Wiedemann LM, Ashworth A, Catovsky D: Frequent somatic deletion of the 13q12.3 locus encompassing BRCA2 in chronic lymphocytic leukemia. Blood 88 : 1568-1575, 1996

117 Vanasse GJ, Halbrook J, Thomas S, Burgess A, Hoekstra MF, Disteche CM, Willerford DM : Genetic pathway to recurrent chromosome translocation in murine lymphoma involves $\mathrm{V}$ (D) $\mathrm{J}$ recombinase. J Clin Invest 103: 1669-1675, 1999 